growing industry, but there are a number of essential oils the development of which might repay close investigation, and further experiment on the cultivation of tung oil by the Agricultural Department is recommended. After a thorough examination of all phases of a cement factory in Northern Rhodesia, the Committee considers that the establishment of this industry holds little prospect of financial success unless a territorial consumption of 20,000 tons a year can be guaranteed for at least fifteen years. Complete information on the coal resources of the Territory is being assembled, and the manufacture of cycles and fibre board, and the formation of a central logging organisation have also received attention. Proposals are advanced for developing the tourist industry, and a memorandum has been submitted to the Government on the importance of increasing the existing power services. There are good technical and economic prospects for a small sheet metal industry to process utensils for African trade, and support is urged for the establishment of the fishing industry on a sound basis. Publication in booklet form of complete information on the mineral resources of Northern Rhodesia is recommended.

\section{Safety of Malaysian Hepaticæ in Germany}

THE Farlow Herbarium of Harvard University has received woy that a valuable collection of more than three thousand specimens of Malaysian Hepaticæ, chiefly opiphytic Lejeuneaceæ gathered by Dr. Frans yerdoorn as well as some other collections assembled by him between 1925 and 1936, which were on loan, at the outbreak of the War, to the Botanical Ingtitute of the University of Jena, is safe. Prof. Th. Herzog who, with a number of assistants and graduate students, is working on this collection writes that he placed most of it, during the early war years, for safeguarding in a country home near Jena. This house was almost entirely destroyed by a bomb; the specimens, however, were found in undamaged condition in the wreckage of the basement. They were later removed to a part of the basement at the Botanical Institute. This building and most of the basement were entirely destroyed at a later date when nine students were killed and the director, Prof. Renner, was seriously wounded. The bryological collections were fortunately in a wing where the basement withstood the bombing, and work on them is now being continued by Prof. Herzog and his assistants, Drs. Benedict and Schuchardt.

\section{Sixth International Congress on Experimental Cell Research}

THe Sixth International Congress on Experimental Cell Resear h is to be held in Stockholm in July 1947. The Congress will be organised by a Swedish working oommittee. Prof. J. Runnström of WennerGrens Institute will act as chairman for the Conference and Pyof. T. Caspersson and Dr. H. Hyden of the Karo/nska. Institute as secretaries. A preliminary programme will be published at the beginning of the autumn. The Conference will include a series of symposia on important problems in experimental cell research from the physico-chemical, physiological and morphological aspects. The Swedish organising committee hopes that cell research workers of all kinds will take advantage of this occasion for exchanging experiences and renewing contact with their colleagues. Suggestions or questions regarding the Conference should be sent to the secretaries.

\section{The Night Sky in September}

Furs moon occurts in Sept. 11d. 09h. 59m. U.T. and new thon on 5 st. 25d. $08 \mathrm{~h}$. $45 \mathrm{~m}$. The following conjunct ons wit the moon take place: Sept. 21d. o4h Saturio S. ; Sept. 27d. 13h., Jupiter $3^{\circ}$ S. ; \$e) 27 d. 1 h., Mars $4^{\circ}$ S. ; Sept. 29d. 00h., Venus t). In addition to these conjunctions with the moon, the following conjunctions occur: Sept. 4d. 03h., Venus in conjunction with Jupiter, Venus $3.5^{\circ}$ S. ; Sept. 25d. 04h., Mars in conjunction with Jupiter, Mars $1 \cdot 1^{\circ} \mathrm{S}$. There is an occultation of $v$ Pisc, reappearance taking place on Sept. 14d. 0Ih. $56 \cdot 2 \mathrm{~m}$. Mercury rises about an hour before the sun on Sept. 1 and can be seen in the eastern sky. The planet is in conjunction with the sun on Sept. 14 and is not favourably placed for observation during the greater portion of the month. Venus sets an hour after the sun on Sept. 1 and 45 minutes after the sun on Sept. 30, attaining its greatest eastern elongation on Sept. 8. During the month the stellar magnitude of Venus varies from -3.9 to $-4 \cdot 2$. Mars and Jupiter are unfavourably placed for observation. Saturn rises at $2 \mathrm{~h}$. on Sept. 1 and at 0h. $19 \mathrm{~m}$. on Sept. 30 and can be sen in the constellation of Cancer in the morning hours. Its stellar magnitude is 0.5 during the month. Autumn equinox occurs on Sept. 23d. 16h.

\section{Announcements}

UNDER the auspices of the Central University, Quito, Ecuador, a general scientific review covering pharmacy, chemistry, physics and biology has been publisk 6 d under the title Revista de la Asociacion Esczela de Quimica y Farmacia. The Director (University, Quito, Apartado No. 166) is anxious to keep in touch with scientific developments everywhere and requests exchanges with similar reviews in America and the Old World.

The Royal Society of New Zealand invites applications for the T. K. Sidey Summer Time Award of a bronze medal and a prize of $£ 100$. The award is mado for scientific research on any kind of electromagnetic radiation (visible or invisible), including its relation to human welfare. Further information may be obtained from the Secretary, Royal Society of New Zealand, Victoria University College, Wellington, New Zealand.

THE report of proceedings of the twentieth conference of the Association of Special Libraries and Informglion Bureaux includes the papers presented at the Conference last September (see Nature, 156 605. 1945) together with notes on the discussions and reports on the work of the ASLIB Microfilm Sorvice and on the British Union Catalogue of Periodicals, and notes on the National Central Library and the Inter-Allied Book Centre. There is also a brief summary of a paper by Mr. E. Reid on the reform of the system of scientific publication by basing it on the individual paper as the unit. Charts displayed at the Conference showing the growth and distribution of the membership of the Association have been reproduced. Additions to the list of desk reference books given by Miss M. Bateman in her paper and suggested by members during the discussion are collected in a useful appendix to that paper. 